DOAN H. GIANG \& V. K. TOKHTAR'

Belgorod State National Research University

Pobeda Street, 85, Belgorod, Russia, 308015.

doan85@mail.ru, tokhtar@bsu.edu.ru

\title{
ECOLOGICAL AND BIOLOGICAL FEATURES OF TROPICAL SPECIES OF THE GENUS MOMORDICA (CUCURBITACEAE) INTRODUCED UNDER THE CONDITIONS OF BELGOROD REGION (RUSSIA)*
}

Keywords: Momordica charantia, Momordica balsamina, grow rate, introduction, drought resistance, Middle

Black Earth zone.

\begin{abstract}
Studies of Momordica charantia L. and Momordica balsamina L. species in the Botanical Garden of the BelSU allowed to estimate plant's growing rate and drought resistance of these perspective plants for introduction. It is established that all studied samples possess rather high degrees of relative drought resistance. It gives a chance to continue further researches on revealing of the most valuable plants of these species for their introduction in culture.
\end{abstract}

\section{Introducation}

The genus Momordica L. belongs to the family Cucurbitaceae; it includes ca. 40 species, which occur mostly in tropical and subtropical regions. The plants are cultivated throughout the tropics, especially in China, India, countries of East Africa, Central and South America.

Species of Momordica are herbaceous, climbing annuals; these fast-growing vines usually need to be trellised. Leaves broadly ovate to orbicular in outline, cordate, deeply palmately 3-7-lobed, cordate at base, apiculate at apex. Flowers yellow, solitary, male and female ones borne on the same plant in leaves axils. Fruit resembling warty gourds or cucumbers, usually oblong. Immature fruits emerald green, turning to orange-yellow when ripe; at maturity, opening into three irregular valves that curl backwards and release brown seeds encased in scarlet arils (Taylor, 2002).

Species of the genus Momordica are economically valuable because they are used in medicine and pharmacy (Abascal \& Yarnell, 2008). Momordica species have a long history of medicinal use, especially in treatment of diabetes - (fresh or dried fruit, dried leaves, vine, whole plant), diarrhea - (leaves), fevers - (stem, vine, whole plant), fungal infections of the skin - (fresh leaves), hypertension - (vine, fresh juice). (Raman \& Lau, 1996; Khan et al., 2005; Abascal \& Yarnell, 2008).

In Russia, these plants are still quite exotic, even though they have a wide range of well-known gardeners. No specific data of studies of these promising plants in the European part of Russia have been found in literature. In Belgorod Region, the presented study was the first one.

\footnotetext{
* The research was carried out under implementation of the project of the Ministry of Education and Science of the Russian Federation by the Belgorod State National Research University
} for 2012 (order No. 5.2614.2011)

(C) DOAN H. GIANG, V. K. TOKHTAR
Climatic conditions of Belgorod Region, despite the rather high level of solar radiation and heat $(150 \mathrm{kcal} /$ $\mathrm{CM}^{2} /$ year), are characterized by low annual rainfall $(400-450 \mathrm{~mm})$ in comparison to other regions of the Russian Federation, which leads to a lack of moisture in the air and soil (Belgorod Meteorological Station. http://meteocenter.net). However, species of the genus Momordica are usually adapted to tropical climate conditions. Therefore, among the limiting factors for their development are the conditions of temperature and humidity in the region where the plants are grown.

The aim of our study was to investigate two species of the genus Momordica, M. charantia L. and M. balsamina L., in the Botanical Garden of Belgorod State University to determine their growth rate and drought resistance. Evaluation of the studied plants will provide opportunities to discover and promote new exotic vegetable plants, promising to be introduced in Belgorod Region and adjacent areas.

\section{Material and methods}

The objects of the study were two species, M. charantia and M. balsamina, obtained from different habitats (Russia (Belgorod), Vietnam, and Germany).

Seeds of both species were planted in greenhouses on April 13,2010 to a depth of $1-1.5 \mathrm{~cm}$ in warm $\left(22-25^{\circ} \mathrm{C}\right)$, moist soil. In order to maintain soil moisture, irrigation was performed every day. Plants were carried out to the open ground by May 17, when the temperature at a $5-\mathrm{cm}$ soil depth reached $20^{\circ} \mathrm{C}$. Plants were transplanted carefully so as not to damage the root system, to prevent illness and death of plants. After transplanting, the plants were fed with a complete mineral fertilizer mixture every two weeks, and during the flowering and fruiting - every week, with low concentrations, one tablespoon (about $5 \mathrm{~g}$ ) of the fertilizer per 81 of water per plant.

The main morpho-physiological parameters of plant were registered for the entire vegetation period (leaf area, height), copse number, flowers appearance and ratio male:female flowers, increase rate of fruits number, in the meantime being also carried out biometrical measurements of fruits.

Accounting for morphological parameters and growth of plants was carried out following the method of Zlobin (Zlobin, 1989). 

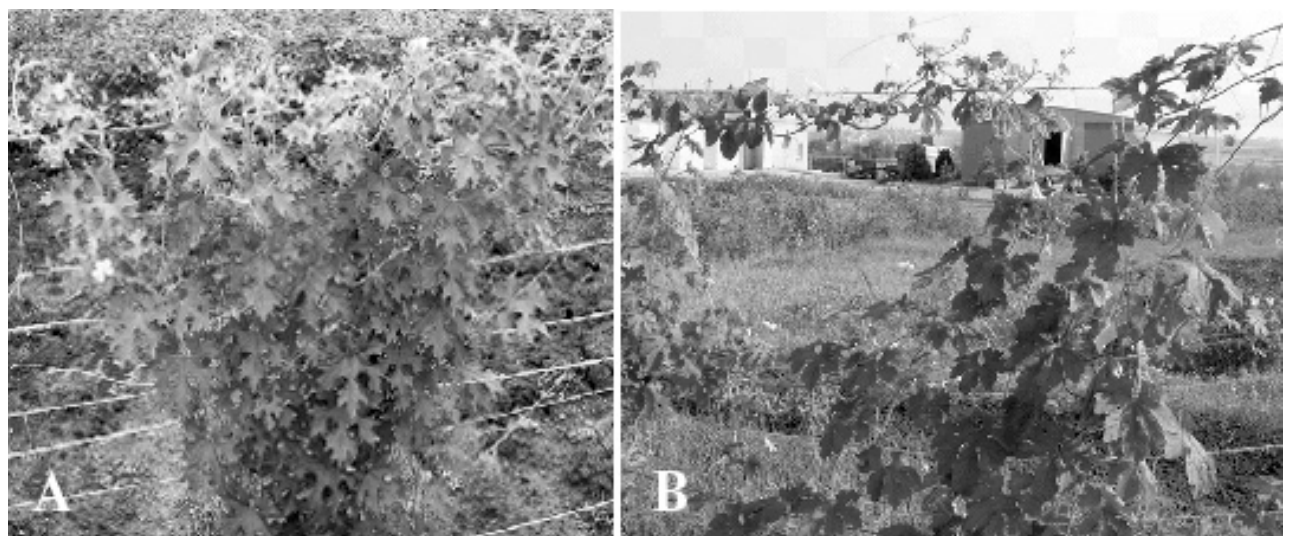

Fig. 1. Plants

M. balsamina L. (A)

and M. charantia L. (B)
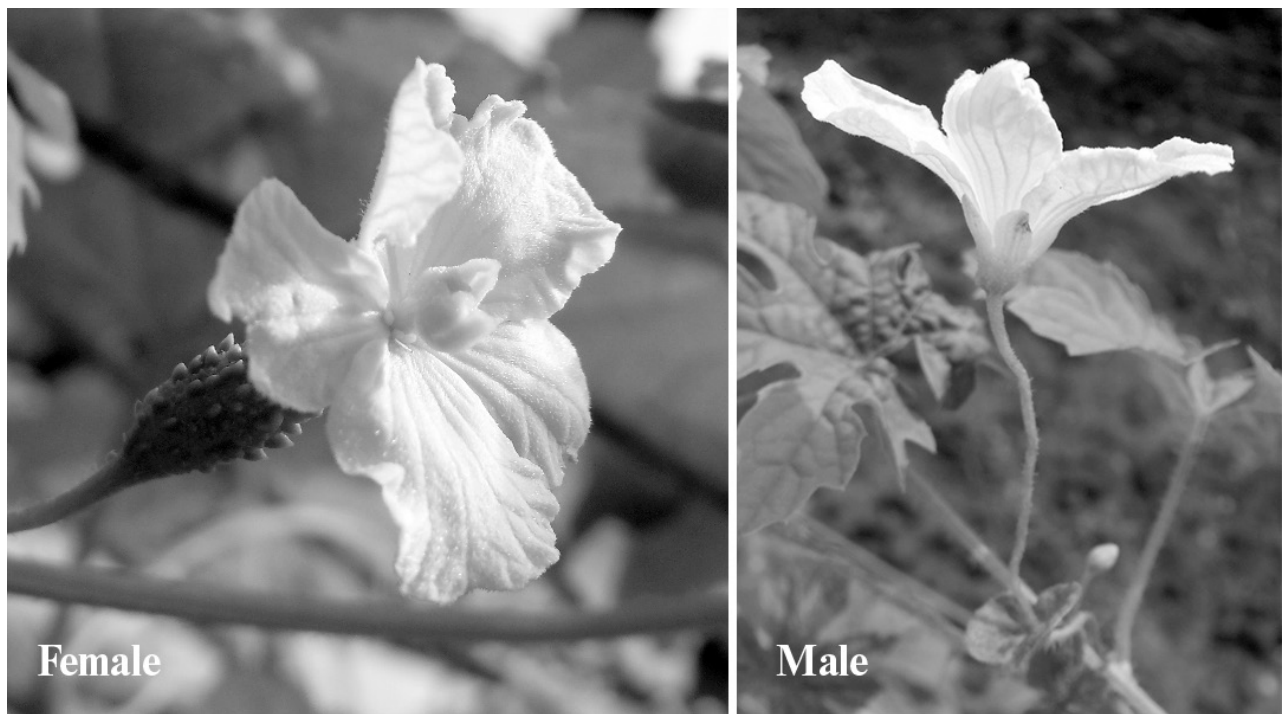

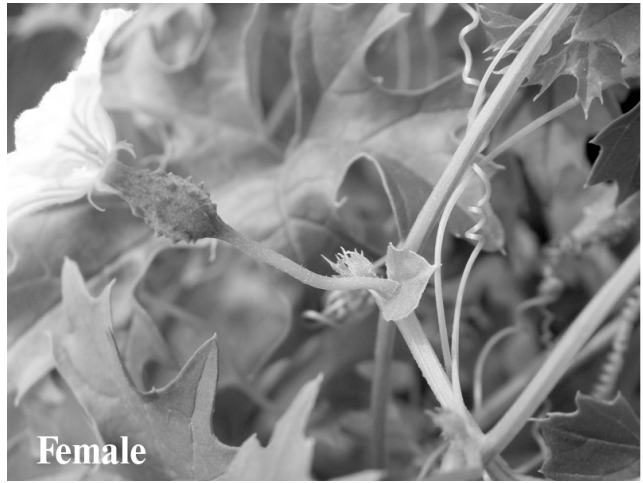

The most informative laboratory and field methods to assess drought resistance are those of studying the water regime of the leaves: determination of water content (total amount of water) in tissues and determination of water-holding capacity of leaves (Kushnirenko et al., 1970). Sampling was conducted in late July - early August, as this period was marked the hottest and most dry weather. Typical leaves were collected from all sides of the plants in the morning, then placed in plastic bags and transferred to the laboratory.
Fig. 2. Flowers of

M. charantia $\mathrm{L}$.

Fig. 3. Flowers of

M. balsamina $\mathrm{L}$. 
Table 1. Climatic data of Belgorod Region (Oblast) Meteorological Station (2010)

\begin{tabular}{|c|c|c|c|c|c|c|c|}
\hline Months & 4 & 5 & 6 & 7 & 8 & 9 & 10 \\
\hline $\begin{array}{l}\text { The average } \\
\text { temperature of the } \\
\text { air, }{ }^{\mathrm{O}} \mathrm{C}\end{array}$ & 9.8 & 17.4 & 22.3 & 25.3 & 25.3 & 14.7 & 4.8 \\
\hline $\begin{array}{l}\text { The average } \\
\text { temperature of the } \\
\text { soil surface, }{ }^{\circ} \mathrm{C} \text {. }\end{array}$ & 11 & 22 & 28 & 30 & 29 & 15 & 5 \\
\hline Relative humidity, $\%$ & 58 & 61 & 52 & 54 & 44 & 69 & 76 \\
\hline $\begin{array}{l}\text { The amount of } \\
\text { precipitation, } \mathrm{mm}\end{array}$ & 16.1 & 25.5 & 20.3 & 41.4 & 24.8 & 84.2 & 43.4 \\
\hline
\end{tabular}

to $2 \mathrm{~cm}$. The general formula for the flowers of both species can be presented as follows:

$$
\begin{aligned}
& \text { j* } \mathrm{Ca}(5) \mathrm{Co} 5 \mathrm{~A}(2+2+1) \\
& +* \mathrm{Ca}(5) \mathrm{Co} 5 \mathrm{G}(\overline{3})
\end{aligned}
$$

The flowers are pollinated by insects. Since the appearance of female flowers, the absence of pollinators does affect the formation of fruit and plant productivity in general. As the flowers rot and fall off very quickly (male flowers last 3 days after the opening of the bud, and female ones, up to 5 days).

These plants are characterized by the absence of clear delimitation between the phases of flowering and fruiting. The flowers open and then fall off, and the fruits are formed in the presence of pollinators during the period of opening the flowers. The process continues until the end of the growing season.

Ripening fruits gradually turn yellow and then become bright orange or red.

Climatic data (temperature, humidity, rainfall) were obtained from the meteorological station of Belgorod Region (Table 1).

The vegetation period of studied plants lasted from May to September, when the temperature was above $15^{\circ} \mathrm{C}$. For samples of both species, the first shoots appeared on the $6^{\text {th }}$ day after seeding. On the $10^{\text {th }}$ day, the plants of $M$. balsamina had the first pair of true leaves, whereas in plants of $M$. charantia this stage of development occurred only on the $13^{\text {th }}$ day. The study found that the development of M. balsamina is characterized by an early start (from seed germination to starting branching), but the late timing of entry into the generative phase (appearance of flowers and fruits). Flowering and fruiting in M. balsamina begin on the $84^{\text {th }}$ and $91^{\text {st }}$ day after seeding, while in $M$. charantia these developmental stages were registered already on the $69^{\text {th }}$ and $81^{\text {st }}$ day, respectively (Table 2 ).

Table 2. Phenological observations on species of Momordica

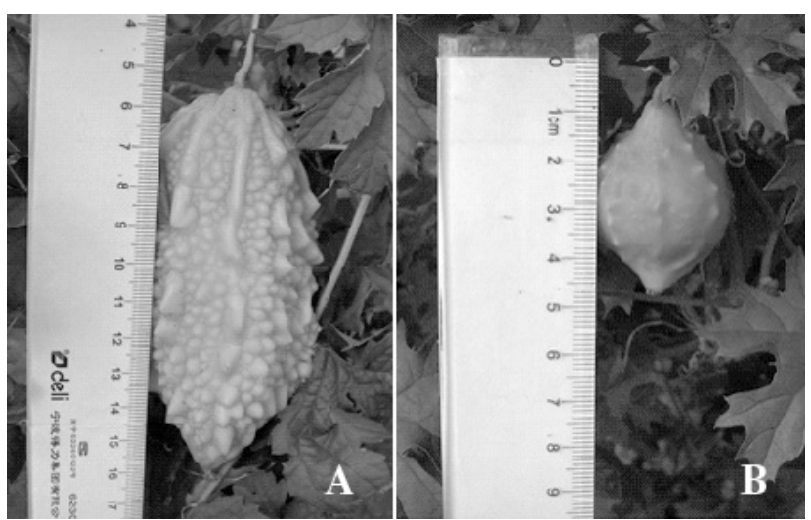

Fig. 4. Fruits of M. charantia L. (A) and M. balsamina L. (B)

In plants of $M$. balsamina we observed an intensive formation of the generative sphere. The number of flowers and fruits per plant was significantly higher than that of M. charantia (Table 3). Both M. charantia and M. balsamina are monoecious plant, i.e., one plant normally develops both female and male flowers. Male flowers appear first; female flowers appear 20-24 days after the male ones.

The fruits of these two species differ both in their form and size. The fruits of $M$. charantia are fusiform, 10$12 \mathrm{~cm}$ long, with numerous tubercles. In M. balsamina the fruits are oval in shape, $3-4.5 \mathrm{~cm}$ long, with broad conical beaks. When ripe, fruits gradually turn yellow and then become bright orange (M. charantia) or red (M. balsamina) (Fig. 4). The average weight values per fruit in $M$. charantia and $M$. balsamina, are, respectively, $59.5 \mathrm{~g}$ and $13.4 \mathrm{~g}$. Fruits of M. balsamina become fully mature in 26 days after formation, whereas in $M$. charantia, after 23 days.

Both studied species of the genus Momordica were characterized by rapid growth during the branching phase before flowering. The absolute increase of major axis is 7.2 and $4.1 \mathrm{~cm}$ per day, respectively, in M. charantia and M. balsamina. After transplantation to the open ground conditions, the plants had no time to adapt to rapid changes in habitat conditions; because of this studied plants from transplant to the phase of active

Table 3. Formation of generative sphere in species of Momordica

\begin{tabular}{lccc}
\hline \multirow{2}{*}{ Species } & \multicolumn{3}{c}{ Average number per plant } \\
\cline { 2 - 4 } & Male flowers & Female flowers & Fruits \\
\hline M. charantia & 68 & 21 & 12 \\
M. balsamina & 124 & 49 & 26 \\
\hline
\end{tabular}

\begin{tabular}{lccccc}
\hline \multirow{2}{*}{ Species } & \multicolumn{4}{c}{ Days after seeding } \\
\cline { 2 - 6 } & $\begin{array}{c}\text { Emergence of } \\
\text { seedlings }\end{array}$ & $\begin{array}{c}\text { Appearance of the first } \\
\text { true leaves }\end{array}$ & $\begin{array}{c}\text { Beginning of } \\
\text { branching }\end{array}$ & $\begin{array}{c}\text { Beginning of flowering } \\
\text { Beginning of } \\
\text { fruiting }\end{array}$ \\
\hline M. charantia & 6 & 13 & 56 & 69 & 81 \\
M. balsamina & 6 & 10 & 50 & 84 & 91 \\
\hline
\end{tabular}




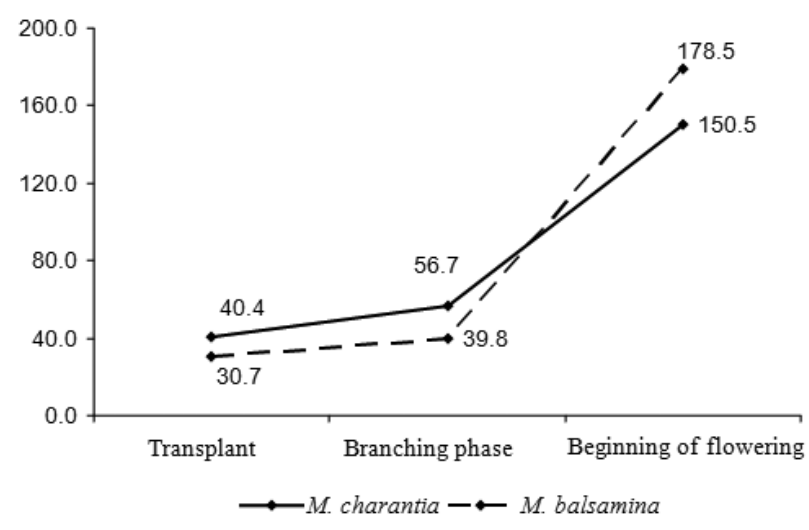

Fig. 5. Growing rate of vine

formation of lateral branches were observed only a small increase (0.4-0.5 cm/day) (Fig. 5).

The results of the study indicate that all studied plants have a high water content in tissues of leaves. The total water content in the leaves of M. balsamina is 77 $\%$ of wet weight, and that in the leaves of M. charantia, about $75 \%$ (Table 4 ). These characteristics are evidence that the presence of water content in the leaves is sufficient for plant life supply of water provided to lack of moisture.

Water-holding capacity is used as the primary indicator of plant resistance to prolonged drought. In our research, the lowest rate of water loss was observed in leaves of M. balsamina $-0.56 \%$ of the total mass after 1 hour of decay, while in the samples of M. charantia it was $1.25 \%$ of the total mass (Table 5).

In such a way both studied species:, M. charantia and M. balsamina, have a high relative drought tolerance. They tolerate dry conditions rather well in Belgorod Region. For the whole period of the study, there has been no damage from lack of moisture in any plant.

Despite the fact that the investigated plants were originally adapted to the warm and humid tropical and subtropical conditions, they can be grown under conditions of lack of moisture and heat in the spring. This is an encouraging result, which allows continuing further studies on the introduction of $M$. charantia and M. balsamina in Belgorod Region.

Table 4. Evaluation of relative degree of drought resistance by water content of tissue

\begin{tabular}{ccc}
\hline \multicolumn{1}{c}{ Species } & Total water content & $\begin{array}{c}\text { Degree of drought } \\
\text { resistance }\end{array}$ \\
\hline M. charantia & 74.68 & High \\
M. balsamina & 77.06 & High \\
\hline
\end{tabular}

Table 5. Assessment of relative drought resistance by water-holding capacity of leaves

\begin{tabular}{ccc}
\hline Species & $\begin{array}{c}\text { The average loss of water } \\
(1 \text { hour }), \%\end{array}$ & $\begin{array}{c}\text { Degree of drought } \\
\text { resistance }\end{array}$ \\
\hline M. charantia & 1.25 & High \\
M. balsamina & 0.56 & High \\
\hline
\end{tabular}

\section{REFERENCES}

1. Abascal K., Yarnell E. Momordica charantia (Bitter Melon) // Bot. Medicine, Integrative Medicine. - 2008. - 7 (1). P. 21-24.

2. Climatic data of Belgorod Oblast Meteorological Station. http://meteocenter.net (20.12.2010).

3. Khan B. et al. Hypoglycemic activity of aqueous extract of some indigenous plants // Pakistan J. Pharmaceutical Sci. 2005. - 18 (1). - P. 62-64.

4. Raman A., Lau C. Antidiabetic properties and phytochemistry of Momordica charantia L. (Cucurbitaceae) // Review Phytomed. - 1996. - 2 (4). - P. 349-362.

5. Taylor L. Technical data report for Bitter Melon (Momordica charantia) // Herbal Secrets of the Rainforest. $2^{\text {nd }}$ edit. Austin: Sage Press, 2002. - 103 p.

6. Zlobin Yu. A. Principles and methods of plant populations study. - Kazan University, 1989. - 149 p. (In Russian).

7. Kushnirenko M. D., Goncharov E. A., Cooper E.M. Methods of water exchange and drought resistance study of fruit plants. Kishinev, 1970. - 79 p. (In Russian).

Commended for publication

S.L. Mosyakin

Submitted 12.07.2012

Доан Х. Жанг, В. К. Тохтарь

Белгородский государственный национальный научноисследовательский университет, Россия

ЭКОЛОГИЧЕСКИЕ И БИОЛОГИЧЕСКИЕ

ОСОБЕННОСТИ ВИДОВ РОДА МОМОRDICA

(CUCURBITACEAE) В ПРОЦЕССЕ ИНТРОДУКЦИИ В УСЛОВИЯХ БЕЛГОРОДСКОЙ ОБЛАСТИ

Исследование видов Momordica charantia L. и Momordica balsamina L. в Ботаническом саду НИУ «БелГУ» (г. Белгород) позволило оценить динамику роста и развития, засухоустойчивость этих перспективных для интродукции растений. Несмотря на то, что изученные виды рода Momordica адаптированы к условиям теплого и влажного климата тропической зоны, они могут выращиваться также при недостатке влаги и тепла в весенний период. Это дает возможность продолжить дальнейшие исследования по выявлению наиболее ценных форм этих видов для введения их в культуру в Белгороде.

Ключ е в ы е сло в а: динамика роста, интродукция, засухоустойчивость, Momordica charantia, Momordica balsamina.

Доан Х. Жанг, В. К. Тохтарь

Білгородський державний національний науководослідний університет, Росія

\section{ЕКОЛОГІЧНІ ТА БІОЛОГІЧНІ ОСОБЛИВОСТІ ВИДІВ РОДУ МОМОRDICA (CUCURBITACEAЕ) У ПРОЦЕСІ ІНТРОДУКЦІЇ В УМОВАХ Б І ЛГОРОДСЬКОЇ ОБЛАСТІ}

Дослідження видів Momordica charantia L. i Momordica balsamina L. у Ботанічному саду НДУ «БілДУ» (м. Білгород) далозмогу оцінитидинаміку росту ірозвитку, посухостійкість цих перспективних для інтродукції рослин. Незважаючи на те, що вивчені види роду Momordica адаптовані до теплого i вологого клімату тропічної зони, вони також можуть вирощуватися в умовах нестачі вологи і тепла у весняний період.

Ключ о в і слов в: динаміка зростання, інтродукція, посухостійкість, Momordica charantia, Momordica balsamina. 